\author{
Hukné Kiss Szilvia - Koltányiné Vadász Viktória \\ Budapesti Gazdasági Egyetem \\ kiss.szilvia@uni-bge.hu \\ koltanyinevadasz.viktoria@uni-bge.hu
}

\title{
PROJEKTEKKEL A MUNKA VILÁGA FELÉ PROJEKTMÓDSZER BEVEZETÉSE A NÉMET ÜZLETI IDEGEN NYELV OKTATÁSÁBAN
}

\section{A kutatás előzményei, alapkoncepciója, célja, stratégiája, elméleti háttere}

Tanulmányunkban egy olyan tananyagfejlesztésről és a hozzá kapcsolódó átfogó kutatásról szeretnénk beszámolni, amely a Budapesti Gazdasági Egyetem Külkereskedelmi Karának Német Tanszéki Osztályán 2016-ban indult meg, és 2019-ben Projektalapú nyelvoktatás egyetemi hallgatók körében címü összefoglaló publikációval (Török et al. 2019) zárult le. Az itt bemutatandó sokrétủ kutatás témái közül tanulmányunk felvázolja a hallgatói motivációra vonatkozó kérdőív tapasztalatait, valamint részletesen bemutatja az egyik tananyagunkban szereplő projekt felépítését, és az ahhoz kapcsolódó kérdőíves felmérés eredményét.

A tananyagfejlesztést az addig tanított, 2010-es fejlesztésủ tananyagunk elavulása indokolta. Ezzel párhuzamosan azonban felmerült az igény egy szemléletmódváltásra is az oktatásban, hiszen nemcsak a hallgatói (a jövendő munkavállalói) igények és a tanulás során mutatott attitüdök változtak meg időközben, hanem a munkaerőpiaci elvárások is. Ezeken felül általánossá vált még az oktatásban is az IKT-eszközök alkalmazása.

A felsőoktatásban jelenleg megjelenő $\mathrm{Z}$ generáció az $\mathrm{X}$ és korábbi generációktól eltérő tanulási szokásairól, okoseszköz-használatáról és megváltozott munkavállalói igényeiről több tanulmány is született (Parment 2009; Bruch-Kunze-Böhm 2010). Összefoglalóan azt lehet kiemelni, hogy a korábbi generációkkal összehasonlítva tanulóként rövidebb ideig tudják fenntartani a koncentrált figyelmet, valamint kevésbé jellemző a lojalitás és a tekintélytisztelet. Pozitívum viszont a megnövekedett tudatosság és önbizalom, továbbá a konkrét elvárások megjelenése a (leendő) munkaadóval szemben.

A munkaadók részéről a munkavállalókkal szemben megfogalmazott követelményekről szintén jelentős számban készültek felmérések és tanulmányok az elmúlt évtizedben (W1, Tóthné-Hlédik 2014; Szakács 2015)

A magánszféra elvárásait nemzetközi szinten immár 20 év óta évenként vizsgálja a PricewaterhouseCoopers Kft., a Munkaadók és Gyáriparosok Országos Szövetségével együttműködve pedig tavaly hatodik alkalommal készített külön Magyarországra vonatkozó felmérést (W2). Mind a nemzetközi, mind a magyarországi felmérések során 
vállalati vezetőket kérdeztek meg. A felmérésben világszerte 1379, Magyarországon 186 vezérigazgató vett részt.

A munkavállalókra vonatkozó válaszokból kiderült, hogy bár a vállalatoknak több mint a fele tervezett 2017-ben létszámnövelést, 2016 és 2017 között növekedett azon cégvezetők száma, akik tartottak attól, hogy nem találnak majd megfelelő szakembert. Mind a kül- mind pedig a belföldi vállalatvezetők véleménye szerint ugyanis a munkavállalónak a megbízható szakmai tudás mellett egy sor kompetenciával (soft skills) is rendelkeznie kell. Ezek a következők: együttműködés és problémamegoldás (92-92\%), alkalmazkodókészség (83\%), kreativitás és innovációs készség (74\%), érzelmi intelligencia (69\%).

A megfelelő munkaerőkínálatból történő merítési lehetőség csökkenése mindazonáltal nem újkeletű felismerés, hiszen a demográfiai változásokat vizsgáló tanulmányok már 2010-ben előrevetítették ezt a tendenciát (Bruch-Kunze-Böhm 2010:42).

A kutatásba először bevont 2017-2018-as tanév őszi szemeszterében a felsőoktatásba belépő elsős évfolyamok várhatóan 2020 folyamán lépnek ki a munkaerőpiacra, így a fent említett eredményeken kívül érdemes figyelembe venni a Világgazdasági Fórum 2017-ben Davosban nyilvánosságra hozott „Tízes listáját” (W3). Ezen a vállalatok által 2020-ban, a majdani negyedik ipari forradalom idején várhatóan legfontosabbnak tartott munkavállalói kompetenciák szerepelnek. A Future of Jobs című jelentés a foglalkoztatást, a munkavállalói kompetenciákat és a munkaerőre vonatkozó vállalati stratégiákat vizsgálta, vezető humánerőforrás szakemberek bevonásával. 2020-ra a harmadik helyen szerepelhet a kreativitás, és a korábbi hasonló listákhoz képest változás, hogy megjelenik elvárásként az érzelmi intelligencia és a kognitív rugalmasság. Ami viszont a várhatóan nem változik, az az, hogy megtartja vezető helyét a komplex problémamegoldó képesség.

A fenti megállapításokból és felmérési eredményekből következik, hogy a felsőoktatásnak - úgy is mint a munkaerőpiac előtti utolsó állomásnak - megfelelően kell reagálni a megváltozott munkaerőpiaci környezetre, valamint igyekezni kell hallgatóinkat a valós munkahelyi elvárásokra felkészíteni miközben az ő megváltozott igényrendszerüket is figyelembe vesszük.

Az új elvárásrendszert alapul véve döntött a BGE KKK Német Tanszéki Osztályának kollektívája a projektalapú oktatás (Project Based Learning) és tanítás (Project Based Teaching) bevezetése mellett. Ez a módszer alkalmazható az idegen nyelv elsajátításának folyamatában is (Project Based Language Learning) elősegítheti a legkeresettebb kompetenciák fejlesztését hallgatóink körében. A Project Based Language Learning kezdete az 1980-as évekre tehető. Kialakulása német nyelvterületen „az idegennyelv-oktatás területén akkortájt virágzó, domináns országismereti irányzatok térnyerésével magyarázható". (Kósik-Kétyi 2017: 95)

A projektalapú nyelvoktatás és nyelvtanulás pontos meghatározása nem egyszerü. Wolfgang Emer és Felix Rengstorf összeállítottak egy metodikai modellt, amely a projektalapú nyelvoktatás jellemzőiként a következőket adja meg: életszerüség, 
komplex feladatvégzés, önálló feladatvégzésre ösztönzés, interdisziplináris munka, kimeneti termékorientáltság, szóbeli kommunikációs készségfejlesztés, valamint társadalmi elkötelezettség (Emer-Rengstorf 2010).

J. W. Thomas a projektalapú nyelvtanulás öt kritériumát nevezi meg, ezek: a projektek központi szerepe a tananyagban, a szakterület lényeges tartalmára történő koncentrálás, a konstruktív felfedezés, a tanulói kezdeményezőkészség és az önálló - tanár által nem irányított - munkavégzés, továbbá az autentikus, a hétköznapi tevékenységgel összefüggő, az iskolai kereteken túlmutató feladat (Thomas 2000).

A két megközelítésben közös, hogy előtérbe helyezik a tanulói önállóságot, az életszerü, az iskolai kereteken túllépő projektfeladatot. Tananyagunk kialakítása során a fejlesztés végző csapat tagjai is erre törekedtek.

\section{A tananyag és a projektek}

A 2018 októberében elkészült új tananyag, mely jelenleg egyetemünk Moodle felületén érhető el, egy modern szemléletű oktatási módszertant vesz alapul. Tematikájában követi a BGE Nyelvvizsgaközpont 2017-ben akkreditált nyelvvizsgájának - az egynyelvü gazdasági kommunikáció szaknyelvi vizsgarendszernek - témaköreit, de nem volt célja közvetlenül a nyelvvizsgára való felkészítés. A tárgyalt témakörök a következők: gazdaság, globalizáció, környezetvédelem, vállalkozás, információs technológia a gazdasági életben, marketing, szolgáltatások, üzleti rendezvények, üzleti utazás, valamint a munka világa.

Tananyagunk egyes fejezeteiben (moduljaiban) egy-egy projekt foglalja el a központi helyet, amelyet a hallgatók véletlenszerủen kialakított és mindig változó 3-4 fós teamekben valósítanak meg, és amelyek során a hallgatók életszerű szakmai kommunikációs szituációkban használhatják a nyelvet. A projektek révén a hallgatók problémákat oldanak meg, és egy kimeneti terméket (online kérdőív, infógrafika, reklámlevél) állítanak elő. A teamek eredményeiket szóban ismertetik (prezentáció), valamint a munkafolyamatot elektronikus úton, idegen nyelven folyamatában dokumentálják is.

A szakmai témakörökhöz való kapcsolódáson kívül az általunk kidolgozott projekteket a következők jellemzik:

- az adott témakör feldolgozásában központi szerepet foglalnak el;

- életszerű szituációkat tartalmaznak, a munka világához kötődnek;

- különböző időtartamúak: 1-3 hét;

- különböző komplexitásúak;

- kis, véletlenszerüen, projektenként mindig újra választott csoportokban (team) valósulnak meg;

- a projektfeladat része a szóbeli és írásbeli kimeneti termék (output);

- a hallgatóktól önállóan megtervezett, megszervezett és kivitelezett - a tanár által nem irányított - feladatvégzést igényelnek; 
- a tanár nem irányít, szerepe a feladat megadására és az értékelésre korlátozódik;

- a hallgatók számára kötelező a projektmegvalósítás folyamatának idegen nyelvű, online dokumentálása egy projektnapló formájában;

- az értékelés a tanár által történik egy pontrendszer alapján, figyelembe véve a projekt során elkészült kimeneti termékeket és a dokumentációt is;

- projektmegvalósítás a dokumentáláson felül is IKT-eszközök alkalmazását igényli.

Az új tananyag és a projektmunka bevezetését akciókutatás kíséri, amelynek során kutatócsoportunk méri és elemzi a kutatásba bevont hallgatói csoportok visszajelzéseit. A kutatócsoport tagjai: Dr. Török Judit, a kutatócsoport vezetője, Fodorné dr. Balthazár Enikő, Hukné dr. Kiss Szilvia, dr. Kétyi András, Koltányiné Vadász Viktória, Kósik Ferenc és Ugrai Zsuzsa. Magának a kutatásnak a hipotéziseit, módszertanát, mérőeszközeit a kutatócsoport tagjai korábbi tudományos konferenciákon már bemutatták (Kósik-Kétyi 2017; Török-Ugrai 2017; Török-Kétyi 2018; Fodorné-Hukné 2018; Hukné-Koltányiné 2018).

Az elkészült fejezetek kipróbálása a 2017-18-as tanév őszi szemeszterében kezdődött meg, a nemzetközi gazdálkodás, ill. a kereskedelem és marketing szak első évfolyamos csoportjaiban (65 fó). A hallgatókat szintező vizsga segítségével négy csoportra osztottuk. Az 1. és a 2. csoport nyelvi szintje a szintezéskor a KER B1+/B2, míg a 3. és a 4. csoporté inkább a KER B1 szintnek felelt meg. A nyelvtanulók a német üzleti idegen nyelvet első idegen nyelvként három féléven keresztül tanulják.

A vizsgálatba később 2018 februárjában bevontuk ugyanazon szak német üzleti idegen nyelvet második idegen nyelvként tanuló másodéves hallgatóit is. Az ő nyelvi szintjük is a KER B1-B2 szintnek felel meg. A tananyagfejlesztési szakasz lezárult, a kipróbálás pedig a 2018-19-es tanév első félévében fejeződött be.

\section{A hallgatói motiváció vizsgálata}

A tananyagkészítéssel párhuzamosan folyó kutatásunk hipotéziseinek megfelelően projektalapú nyelvoktatás bevetésétől 3 változást prognosztizáltunk:

H1: A hallgatók problémamegoldó képessége fejlődni fog a célnyelv autentikus szituációkban való használatával.

H2: A hallgatók az újszerủ módszerek hatására motiváltabbá válnak.

H3: Az oktatói együttműködés is intenzívebbé, hatékonyabbá válik.

Kutatásunkban számos saját fejlesztésü kvalitatív és kvantitatív mérőeszköz segítségével végzünk elő- és utóméréseket. 2017 őszén mintánkat $(\mathrm{N}=65)$ a BGE KKK elsőéves német nyelvet tanuló hallgatói képezték. Velük 2018 májusában megtörtént a köztes mérés is, decemberben pedig utómérés. 2018 februárjában újabb 60 hallgatót vettünk be a kutatásba, akik másodévesként kezdték a német üzleti nyelvet tanulni, 2018 szeptemberében pedig az új elsősök is bekapcsolódtak a mérésekbe 66 fővel. A kutatás teljes spektrumában részt vevő hallgatókon kívül a motivációs kérdőívet más csoportokban is kitöltettük, így 
a teljes mintaszám 243 fö. A Likert-skálás kérdőívünk 33 kérdése 6 téma köré csoportosult: 1. Mit tartanak a hallgatók a nyelvtanulás legfőbb előnyeinek?

Szinte minden hallgató teljes mértékben egyetértett azzal, hogy a német nyelvtudása előnyös: jobb álláshoz és magasabb fizetéshez segíti majd. Érdekes, hogy sokan azért tanulják éppen a német nyelvet, mert a német nyelvű országok gazdaságát jelentősnek tartják, és a hallgatók több mint fele szívesen dolgozna a későbbiekben valamely német nyelvü országban (1. ábra).

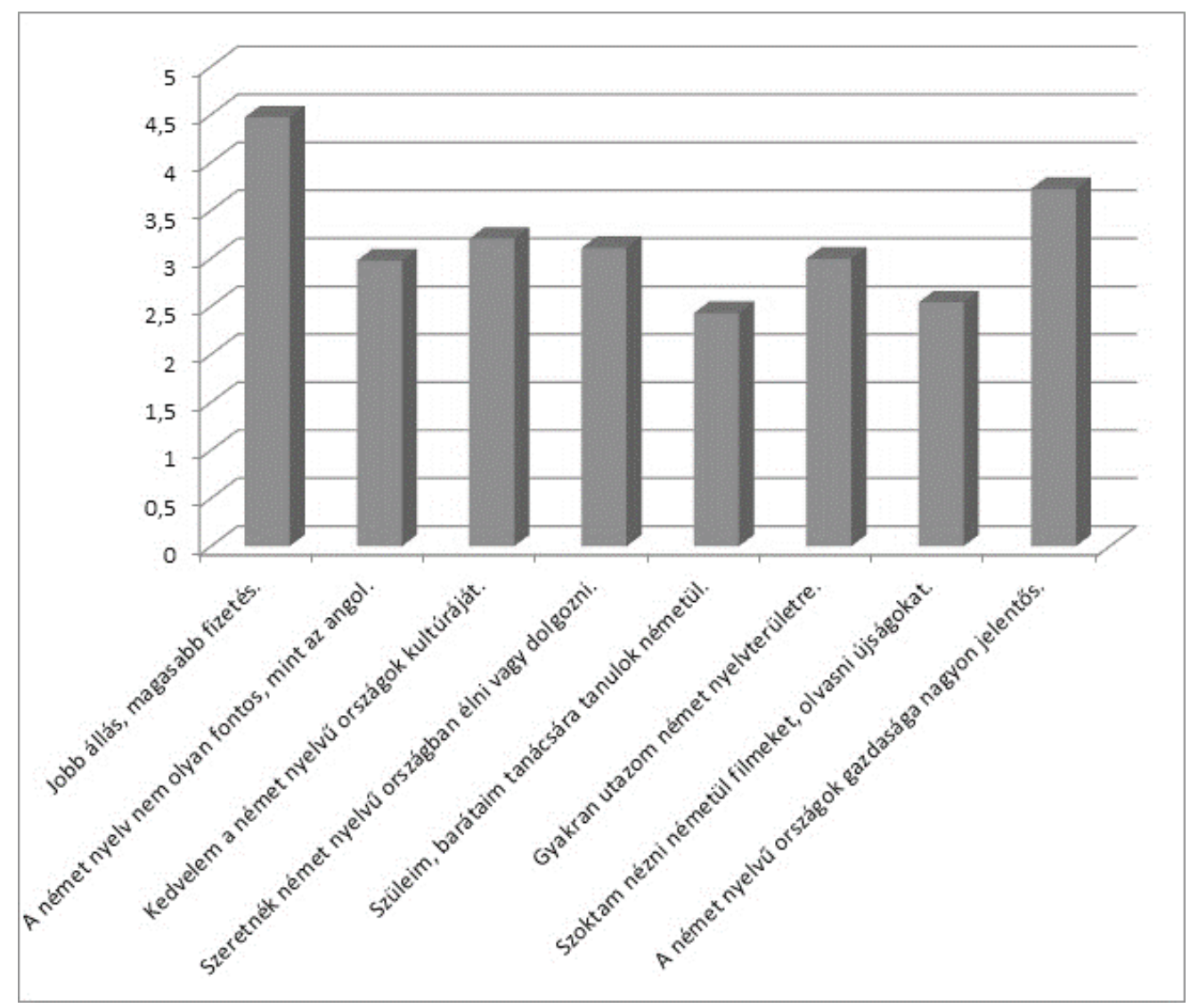

1. ábra: Mit tartanak a hallgatók a nyelvtanulás legfőbb előnyeinek?

2. Milyen tapasztalataik vannak a hallgatóknak általában a nyelvtanulás folyamatáról? A kérdőív második, a tanulási folyamatát vizsgáló részénél azt tapasztaltuk, hogy a hallgatók zöme - saját állítása szerint - hajlandó komoly erőfeszítést tenni a nyelvtanulás érdekében, és azt gondolják, hogy ezzel el is érik céljukat, és megszerzik tanulmányaik végére a középfokú nyelvvizsgát. A megkérdezettek többsége a nyelvtanulást kreatív folyamatnak tartja, és örül, ha a tanár rájuk bízza, hogy hogyan oldanak meg egy problémát (2. ábra). 


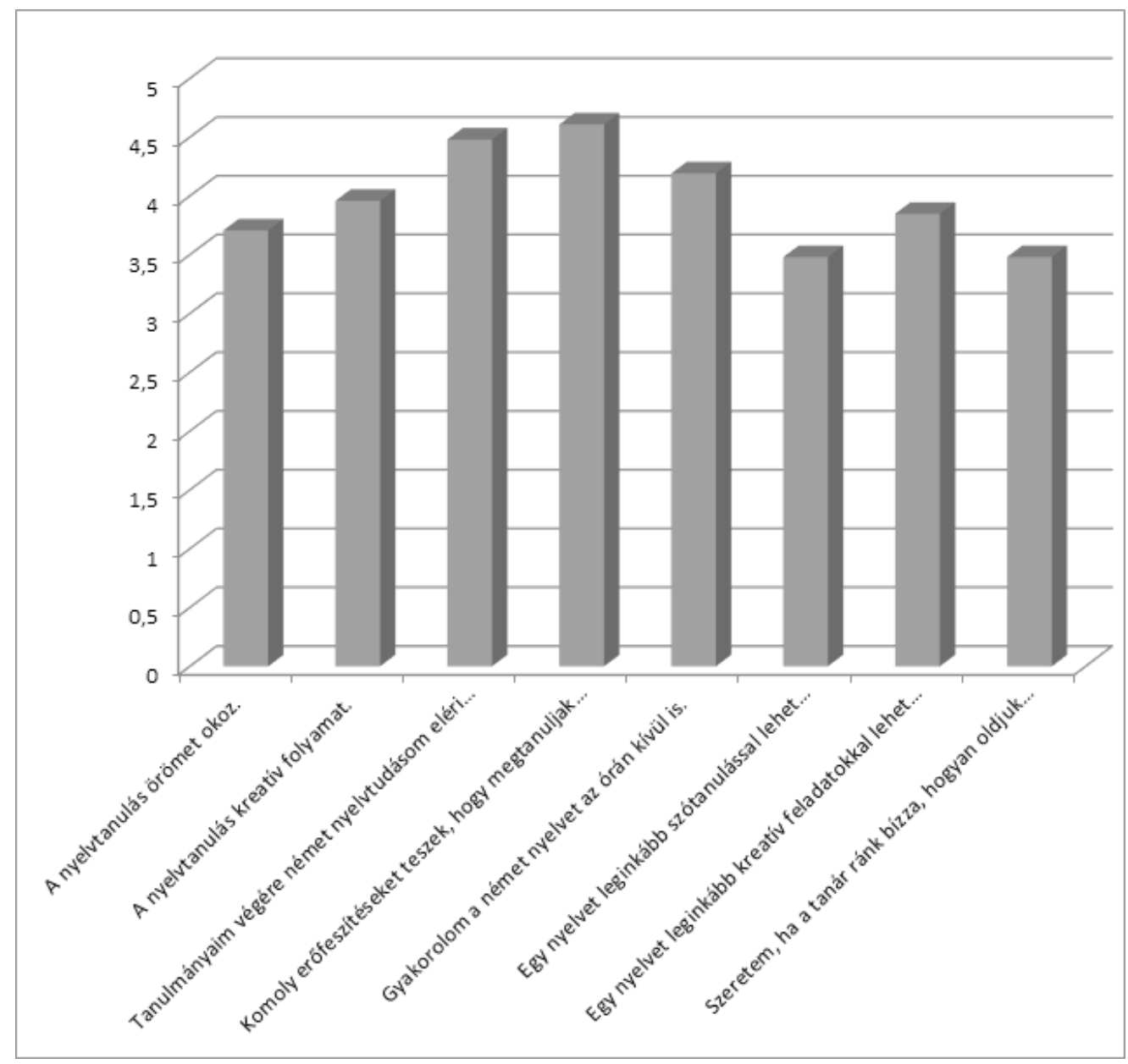

2. ábra: Milyen tapasztalataik vannak a hallgatóknak általában a nyelvtanulás folyamatáról?

3. Hogyan viszonyulnak a hallgatók a tanári, illetve tanulói visszajelzésekhez? A tanári és tanulói visszajelzésekkel kapcsolatban kutatásunk azt az eredményt hozta, hogy a tanári visszajelzések (pozitív és negatív egyaránt) jobban hatnak a hallgatókra, mint a csoporttársaik véleménye, különösen a kritikát nem fogadják el szívesen társaiktól (3. ábra). 


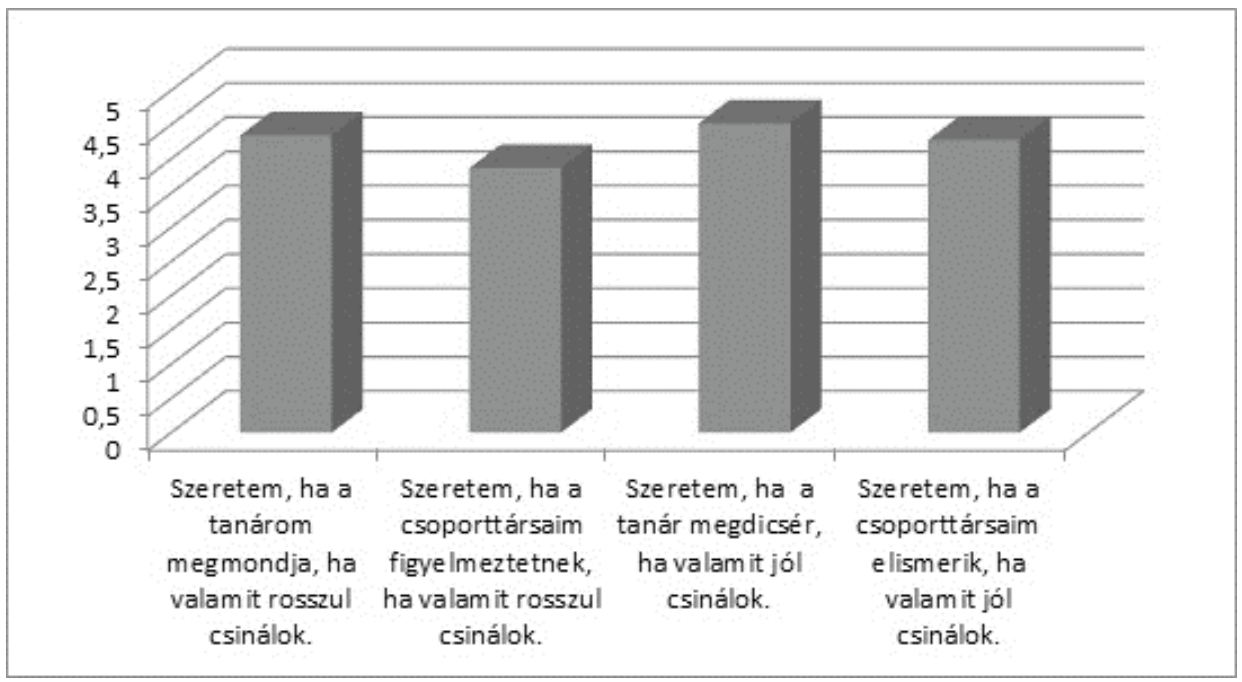

3. ábra: Hogyan viszonyulnak a hallgatók a tanári ill. tanulói visszajelzésekhez?

4. Hogyan hatnak a hallgatókra a külső motivációs tényezők?

A külső motivációs tényezők közül elsősorban a jó jegy és a tanár hat motiválóan a hallgatókra, legkevésbé pedig a határidők (4. ábra).

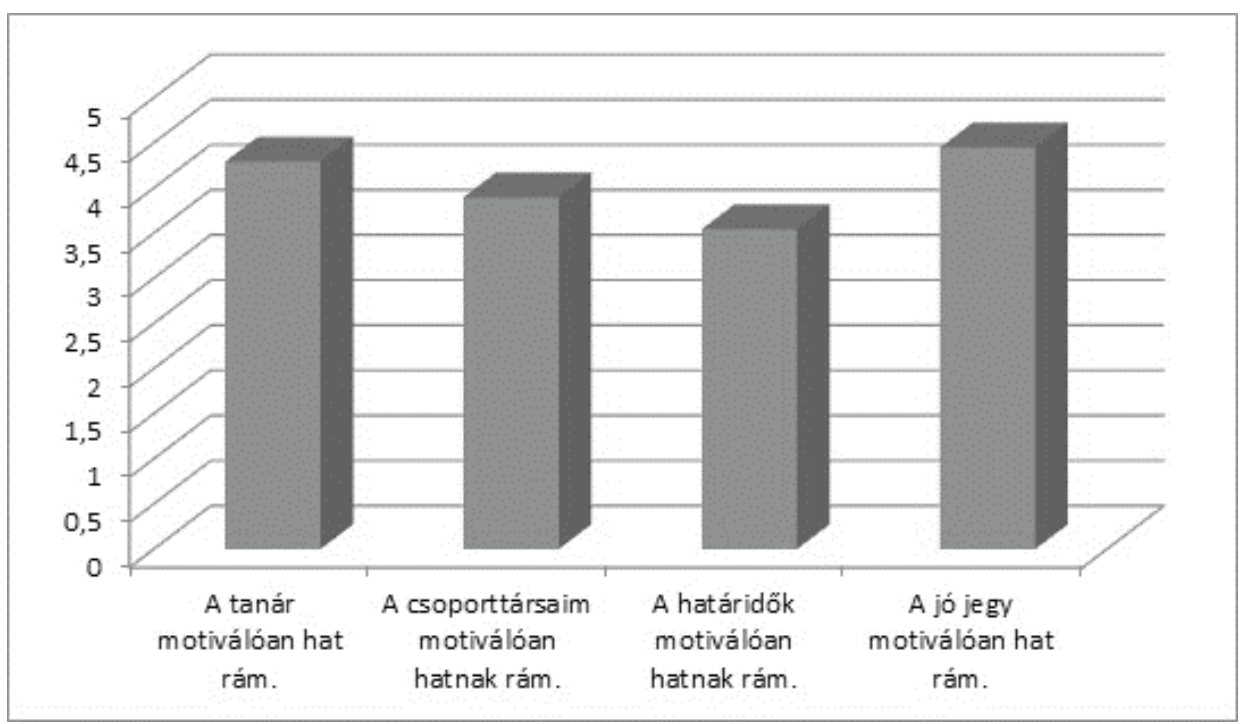

4. ábra: Hogyan hatnak a hallgatókra a külső motivációs tényezők? 
5. Hajlandóak-e a hallgatók kellő időt fordítani a nyelvtanulásra?

A hallgatóink állandó időzavarral küzdenek, mégis azt állítja szinte mindenki, hogy hajlandó a szükséges időt maximálisan rászánni a nyelvi feladatai elvégzéséhez, viszont a nyelvórán kívül csak kb. fele részben foglalkoznak a német nyelvvel (5. ábra).

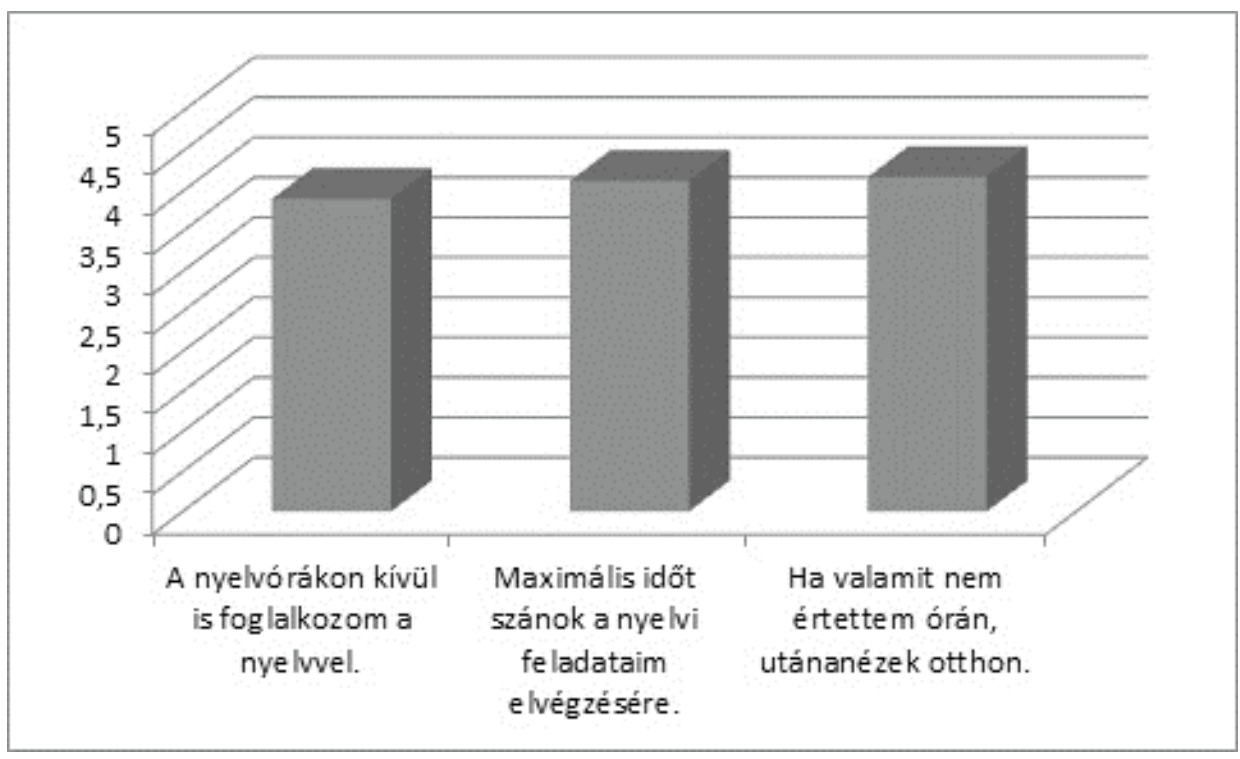

5. ábra: Hajlandóak-e a hallgatók kellő időt fordítani a nyelvtanulásra?

6. Milyen a hallgatók együttműködési hajlandósága a nyelvórákon?

A kérdőív együttműködési hajlandóságot vizsgáló kérdéseire kapott válaszok alapján megállapítható, körülbelül ugyanolyan mértékben szeretik hallgatóink a csoportos, illetve páros feladatokat. A csoportos feladatoknál a többség mindent megtesz a csoport sikeréért, és ezt a társaitól is elvárja. A hallgatóink kb. fele nem szeret a csoporton belül vezető lenni (6. ábra). 


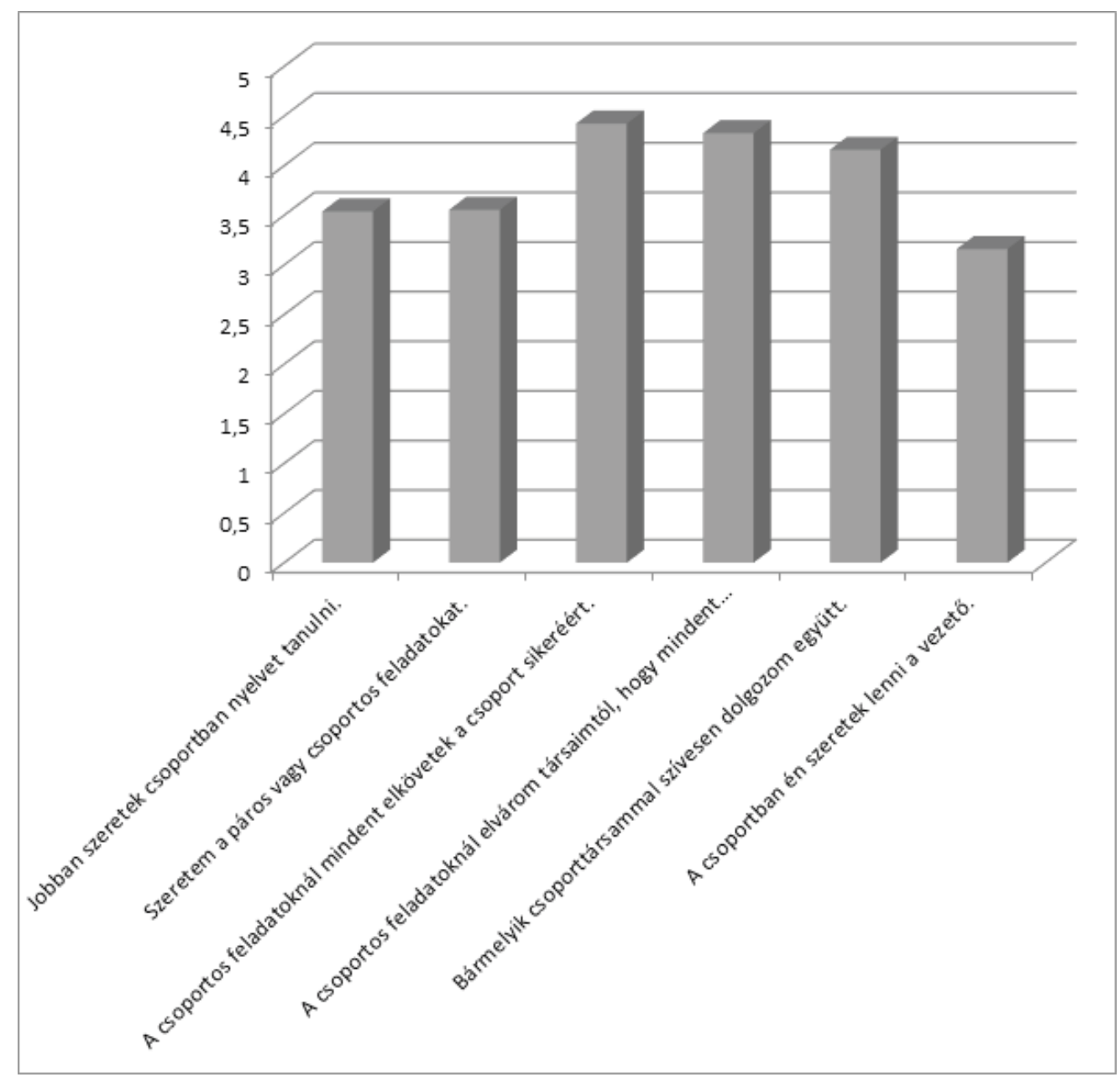

6. ábra: Milyen a hallgatók együttmüködési hajlandósága a nyelvórákon?

A kutatásba elsőként bekapcsolódott 65 fóvel két szemeszter után megtörtént a második mérés is. 58 olyan hallgató volt, aki mindkét kérdőívet kitöltötte. Tapasztalataink a következők: a kérdések túlnyomó részében nem találtunk szignifikáns eltérést a 2017. szeptemberi és 2018. májusi válaszok között. Összesen négy kérdésnél volt 0,2-nél nagyobb a különbség a két időszak eredményei tekintetében:

- Csökkent a csoporttársak motivációja („Csoporttársaim motiválóan hatnak rám.” $-0,23)$

- Csökkent a jó jegy motivációja („A jó jegy motiválóan hat rám”-0,21).

- A csoportmunka esetleges zökkenői miatt kissé esett annak a pozitív megítélése, hogy a tanár/sorsolás adja meg a csoport összetételét („Szeretem, ha a tanár mondja meg, hogy kivel kell együtt dolgoznom.” -0,22). 
- Pozitívan értékelendő, hogy két projektoktatásban eltöltött szemeszter után többen érzik úgy, hogy több időt szeretne nyelvtanulásra szánni. („Több időt szeretnék fordítani nyelvtanulásra. +0,21) (7. ábra).

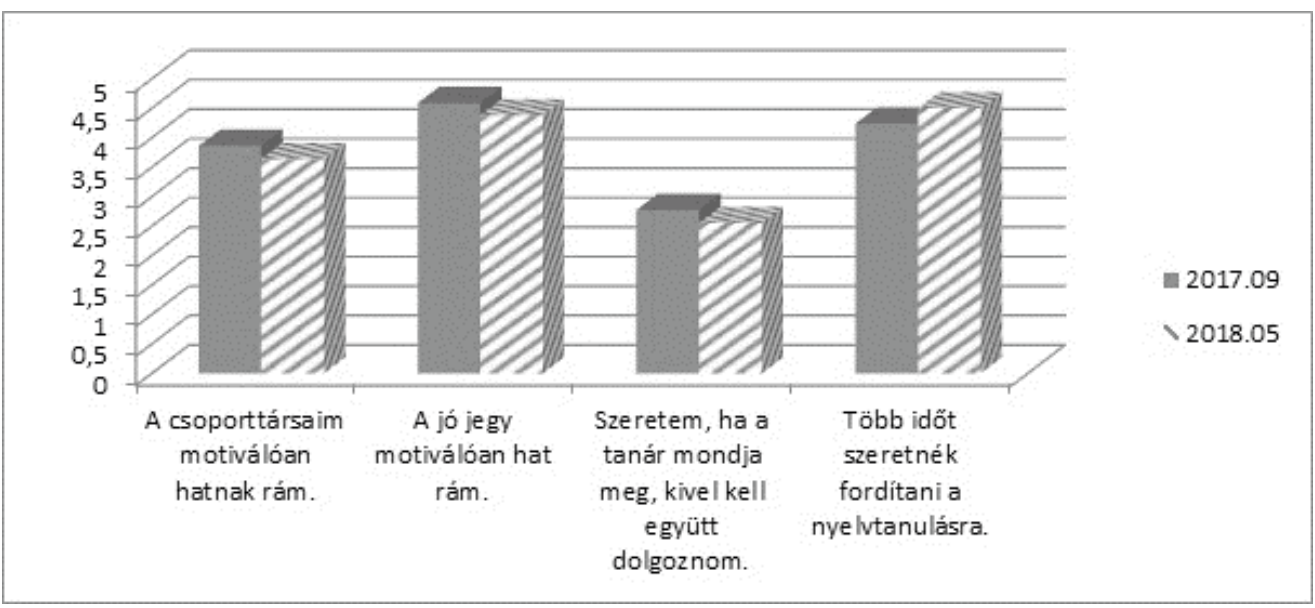

7. ábra: Eltérések 2017-2018

A kutatócsoport úgy értékelte, hogy a motiváció vizsgálatával kapcsolatos eredmények további, kvalitatív kutatást igényelnek. Ezért a 2018. decemberi utómérést követően 2019 tavaszán fókuszcsoportos interjúkat készítettünk hallgatóinkkal, melyek eredményeit egy másik publikációban mutattuk be (Török et al. 2019).

\section{A Banken mal anders (Bankolj másképp) projekt bemutatása}

A korábban említett projektjellemzőket a következőkben egy konkrét példán mutatjuk be: a Banken mal anders/Bankolj másképp projektünkön. Tematikailag ez a projekt a harmadik (utolsó) félévet nyitja meg, vagyis eddigre a hallgatók már megismerték és megszokhatták a projektfeladatokkal járó tevékenységeket (teamek felállítása, az együttműködés csatornáinak megszervezése, az önálló - tanár által nem irányított - feladatvégzés, valamint a kimeneti termékek elkészítése) és számos különböző típusú outputot is készítettetek (interjú, videó, kérdőív, költségkalkuláció). A szaknyelvi órákon végzett projekteknél véleményünk szerint fontos hangsúlyozni azt a tényt, hogy ellentétben a valós üzleti életben elvégzett projektfeladatoknál, itt nemcsak - vagy nem elsősorban - a tervezett kimeneti termék (output) a fontos, hanem a projektfeladat során megtett út is. Amellett, hogy hallgatóink ismerkedjenek a projektrendszerű feladatvégzéssel, szaknyelvet oktatókként elsődleges számunkra az is, hogy a megfelelö szakszókincset megismerjék, az, hogy minél többet kommunikáljanak (egymás között) idegen nyelven, valamint szaknyelvi szövegeket tudjanak létrehozni, és tudják a saját munkájukat idegen nyelven értékelni. A modul címe: Gute 
Zeiten - Schlechte Zeiten (Banken)/ Jóban rosszban (Bankok). A modul felépítése - amely egyébként megegyezik a többi moduléval - a következő:

- Vorentlastung/Előzetes ráhangolódás a témára: jelen esetben az hallgatók által használt szolgáltatatásoktól jutunk el konkrétan a banki szolgáltatásokig.

- Wissenswertes: ez a rész tartalmazza a témához kapcsolódó legfontosabb tudnivalókat, fogalmakat, ismereteket.

- Praktisches: itt sajátíthatja el a hallgató a témához kapcsolódó gyakorlati ismereteket és a hozzájuk tartozó szakszókincset. Például: Számlanyitás, megtakarítási formák, online bankolás előnyei és hátrányai.

- Grammatik: ez az egység tematikus nyelvtani leíró részt és gyakorló feladatsorokat tartalmaz, a KER/B2-es nyelvi szinthez igazodva.

- Projekt: az ötödik rész a modulban a tulajdonképpeni projektleírás. A Moodle felületen magának a projektnek a leírása külön jelenik meg, fontosságát hangsúlyozandó. A projekt a modul órai feldolgozásával párhuzamosan - a témához tartozó alapismeretek és szókincs megismerése után - indul. A projekt leírásában törekedtünk a részletességre, így az tartalmazza a projektleírás mellett az ütemezést, a felhasználandó IKT-eszközöket, linkeket, valamint az elvárt szóbeli és írásbeli kimenetet is.

A projektekhez külön szószedet is tartozik, amelyet a Quizlet program segítségével dolgoztunk fel, lehetőséget biztosítva a hallgatók számára a szakszókincs játékos elsajátítására. Mint már említésre került, a projekt leírásban törekedtünk a részletességre. Így a hallgatók a projekt leírása mellett, a projekt elvégzésével elérendő célt is megismerik, így tudatosabban vághatnak bele a feladatba:

\begin{tabular}{|l|l|}
\hline Projektbeschreibung: & $\begin{array}{l}\text { Die Studierenden entwickeln ein neues Produkt oder eine neue } \\
\text { Dienstleistung einer fiktiven Handelsbank mit Bestimmung } \\
\text { einer konkreten Zielgruppe. Sie erstellen ein Flugblatt oder } \\
\text { einen kurzen Katalog und präsentieren die Projektergebnisse. }\end{array}$ \\
\hline Projektleírás: & $\begin{array}{l}\text { A hallgatók feladata, hogy egy új, konkrét célcsoportra kidol- } \\
\text { gozott kereskedelmi banki szolgáltatást fejlesszenek ki. Az új } \\
\text { szolgáltatást banki szórólap vagy rövid ismertető formájában } \\
\text { népszerüsítsék, és szóban mutassák be a projekt elvégzése során } \\
\text { elért eredményeket. }\end{array}$ \\
\hline Projektziel: & $\begin{array}{l}\text { Die Studierenden machen sich ein Bild über die } \\
\text { Finanzdienstleistungen und -produkte. Sie können ihrer } \\
\text { Kreativität freien Lauf lassen indem sie eine neue Idee } \\
\text { entwickeln. }\end{array}$ \\
\hline Projektcél: & $\begin{array}{l}\text { A hallgatók feltérképezik, és ezáltal megismerik a pénzügyi } \\
\text { szolgáltatások és termékek körét. Teret adnak kreativitásuknak } \\
\text { és kifejlesztenek egy új banki terméket. }\end{array}$ \\
\hline
\end{tabular}


Az időkeret (ennek a projektnek az esetében két hét) és a projekt megvalósításához szükséges eszközök mellett a hallgató megismerheti a projekt tervezett ütemezését is:

1. Első tanóra: A projekt előkészítése, a projektszabályok ismertetése, a teamek megalkotása, az időkeret meghatározása, az értékelés szempontjainak megbeszélése (20 perc). A kereskedelmi bankok termékeinek és szolgáltatásainak feltérképezése. Itt nincs javasolt módszer, a kurzust tartó tanár döntheti el, hogy milyen módszert alkalmaz (pl. mind mapping) (70 perc).

2. Önálló projektmunka: Az első órán megalakult kiscsoportok (teamek) végzik, saját ütemezésben, saját időbeosztással, a feladatok meghatározásával (1,5 hét).

3. Második tanóra: A projekt zárása. A teamek kb. 10 perces prezentáció keretében bemutatják a kurzus résztvevőinek az általuk kifejlesztett banki terméket illetve szolgáltatást. A kurzus résztvevői pedig a kutatócsoport által kifejlesztett értékelőlapokon értékelik azt, majd az előadók is értékelik (szintén írásban) saját szereplésüket (60 perc). Az elkészült szórólapok és ismertetők rövid bemutatása (15 perc). A hallgatók megszavazzák a számukra legszimpatikusabb ötletet (15 perc).

A projekt értékelése a kurzust tartó tanár által történik. A team tagjai - kirívó esetektôl eltekintve - ugyanazt az érdemjegyet kapják. Az értékelés szempontjai a hallgatók számára is ismertek, benne a szóbeli és írásbeli output értékelésén kívül helyet kap a projektmunkával párhuzamosan, a team összes tagja által idegen nyelven vezetett írásos dokumentáció, az ún. Projektjournal/projektnapló értékelése is

A projektnaplók három fö részt tartalmaznak:

- Bevezető: A projekt adatai és a feladatkörök meghatározása.

- A munkavégzés folyamatát dokumentáló rész. (Időráfordítás, részfeladatok, nehézségek.)

- Az összegző rész (ún. Ergebnisprotokoll).

\section{A banki projekt kérdőíveinek értékelése}

A kutatás részét képezi egy online kérdőív, melyet a hallgatók minden projekt végén kitöltenek. Az általunk bemutatott projektre vonatkozóan 50, különböző nyelvi szinttel (B1-C1) rendelkező hallgató értékelése szerepel a mérésben (22 férfi, 28 nő, átlagéletkoruk 20,22 év).

A mérés eredményeit a következőképpen foglalhatjuk össze:

\section{a. A projekt megítélése általában:}

„Hogyan értékelné a most befejezett konkrét projektet?” Az 1-5-ig terjedő Likert-skálás kérdésre beérkezett válaszok átlaga: 4,02, tehát megállapítható, hogy a projekt igen kedvelt volt a megkérdezettek körében. 


\section{b. Hasznosság:}

„Véleménye szerint hasznos volt a projekt, tanult valamit a projekt során? Kérem, írja le röviden a tapasztalatait." A válaszok között 4 nem és 46 igen szerepel. Az indoklások között első helyen állt a szókincs bővülése, a kreativitás fejlesztése és a teammunka gyakorlása. Egy hallgató azt is megemlítette, hogy ötletet adott neki egy későbbi saját vállalkozáshoz.

„Elősegítette-e a projektfeladat a nyelvi fejlődését, ha igen, mely területen?” A válaszok között 4 nem és 46 igen szerepel. Az igennel válaszolók közül 55\% (25 fö) a szókincs, 15\% (7 fö) a pénzügyi ismeretek, 13\% (6 fö) a beszédkészség területét jelölte meg, amelyben a legtöbbet fejlödött a projekt során. Egy-egy fö említette a nyelvhasználat, az íráskészség, a szótározási készség és a problémamegoldó képesség fejlődését.

\section{c. Együttmüködés:}

„Merültek-e fel problémák a projektmunka során?” A válaszok között 34 nem és 16 igen szerepel. A projekt során a legtöbb problémát a csapatmunka nehézségei (6 fö), az ötlethiány (3 fö), a projektnapló vezetése ( 2 fö), a feladatok felosztása (2 fó) és az időhiány (1 fö) jelentette.

„A projekt során sikerült-e együttműködnie a team többi tagjával? Írja le röviden a tapasztalatait." 42 hallgató válaszolt úgy, hogy teljesen sikerült, 3 hallgatónál nem sikerült, 5 esetében pedig csak részben sikerült. A részletesebb válaszokból az is kiderült, hogy minek tulajdonítják a sikeres együttműködést. Ezek a faktorok a következők: jó időmenedzsment, jól működő csapatmunka, egymás segítése, sikeres ötletelés. A legtöbben azt említették, hogy mindenki tudta, hogy mi a feladata és azt rendesen elvégezte. A jó együttműködést akadályozta a nem arányos munkafelosztás, a rossz időmenedzsment és a teammunka hiánya.

\section{d. Saját szerep}

„Hogyan értékeli tevékenységét a csoportjában? Hogy érezte magát benne? Írja le röviden a tapasztalatait." Két fó adta azt a választ, hogy nem érezte jól magát a projekt során. Ennek oka mindkét esetben az volt, hogy sokkal többet kellett dolgoznia, mint csoporttársainak. 36 fó jelezte, hogy jól érezte magát. Az indokok között szerepelt, hogy jó teamet alkottak, egyenlően osztották fel a munkát, összhangban voltak, mindenki megtett mindent a sikerért, jól telt az idő, hasznosnak érezték magukat. 3 hallgató jelezte, hogy ő volt a csapat „kulcsembere”, de ezt pozitívumként értékelte.

\section{e. Tanulságok}

„Ha lehetne, mit csinálna másképp?” A megkérdezettek 44\%-a (22fö) semmin sem változtatna. Akik valamit másként csinálnának, azoknál a következő faktorok kerültek említésre:

- idő (több időt szánna rá /hamarabb kezdené a munkát),

- elpróbálná a prezentációt, 
- jobb plakátot/prezentációt készítene,

- jobban megtanulná a szöveget,

- egy fő említette, hogy máskor szívesebben választaná ő ki a csapattársait.

\section{6. Összefoglalás}

A projektalapú nyelvoktatás bevezetése, a projektek kifejlesztése, az új tananyag megírása és a kutatás egy időben zajlott. A kutatócsoport tagjaiban a munka során több kérdés is megfogalmazódott. A legtöbbször felmerült kérdések, illetve a kutatócsoport válaszai a következők voltak:

1. Szükséges-e minimális nyelvtudás a projektek végrehajtásához? Tapasztalatunk szerint A2 tudásszint felett képesek a hallgatóink értékelhető munkát végezni, A2 szint alatt nem segítik a projektjeink a nyelvtanulást.

2. Igazságos-e a csoportszintủ értékelés? Úgy gondoljuk, azzal, hogy a team közös teljesítményére valamennyi tag azonos jegyet kap, felkészítjük hallgatóinkat a munkaerőpiacon rájuk váró szituációkra. Az egységes értékeléstől csak egy-két extrém esetben kellett eltérnünk.

3. Hogyan tudjuk az órai nyelvhasználatot mérni? Egyelöre a technikai lehetőségeket korlátozottnak tekintjük, de dolgozunk a módszer kialakításán.

Az utóméréseket, valamint a kvalitatív kutatások egy részét jelen tanulmány elkészülte után végeztük. Az eredményektől egy összefoglaló tanulmányban számoltunk be (Török et al. 2019).

\section{Irodalom}

Bruch, Heike - Kunze, Florian - Böhm, Stephan 2010. Generationen erfolgreich führen: Konzepte und Praxiserfahrungen zum Management des demographischen Wandels. Wiesbaden: Springer Verlag. https://doi.org/10.1007/978-3-8349-8506-4

Emer, Wolfgang - Rengstorf, Felix 2010. Bedeutung einer Projektkultur an Schulen und ihre Merkmale. In: TRIOS - Forum für Schulnahe Forschung, Schulentwicklung und Evaluation 2. Münster: LIT Verlag. 17-21.

Fodorné Balthazár Enikő - Hukné Kiss Szilvia 2018. Projekt a nyelvórán? Egy projektalapú üzleti nyelvi tananyag fejlesztése és a projektmódszer bevezetése a német nyelvoktatásban. In: Bodáné Kendrovics Rita (szerk.): Hazai és külföldi modellek a projektoktatásban: Nemzetközi Tudományos Konferencia tanulmánykötete. Budapest: Óbudai Egyetem Rejtő Sándor Könnyüipari és Környezetmérnöki Kar. 108-121.

Hukné Kiss Szilvia - Koltányiné Vadász Viktória 2018. Projektmunka a motiváció és az értékelés tükrében A BGE KKK-n német szaknyelvoktatásban részt vevő két hallgatói csoportban végzett összehasonlító kutatás. Nyelvvilág 21: 24-34. 
Kósik Ferenc - Kétyi András 2017. A projektalapú nyelvtanulás bevezetése a német üzleti szaknyelvi képzésbe. In: Bodáné Kendrovics Rita (szerk.): Hazai és külföldi modellek a projektoktatásban: Nemzetközi Tudományos Konferencia tanulmánykötete. Budapest: Óbudai Egyetem Rejtő Sándor Könnyűipari és Környezetmérnöki Kar. 91-102.

Parment, Anders 2009. Die Generation Y - Mitarbeiter der Zukunft: Herausforderung und Erfolgsfaktor für das Personalmanagement. Wiesbaden: Gabler.

https://doi.org/10.1007/978-3-8349-8802-7

Szakács Édua 2015. Az egyéni és a szociális kompetenciák szerepe a karrierindításban (avagy a sikeres pályakezdők titka a közszférában és a magánszektorban). Hadtudomány 25: 85-91.

Thomas, John W. 2000. A Review Of Research On Project-Based Learning. http://www. bobpearlman.org/BestPractices/PBL_Research.pdf (2018. 04. 11.)

Tóthné Téglás Tünde - Hlédik Erika 2014. Mit várnak el a nagyvállalatok a pályakezdőktől? In: Nagy Imre Zoltán (szerk.): Vállalkozásfejlesztés a XXI. században: IV. tanulmánykötet. Budapest: Óbudai Egyetem Keleti Károly Gazdasági Kar. 387-408.

Török Judit - Kétyi András 2018. Projektúra: a projektalapú nyelvtanulás német szaknyelvi csoportokkal: Projectour: project based language learning with business German groups. Multidiszciplináris kihivások, sokszinü válaszok 3: 96-110.

Török Judit - Kétyi András - Hukné Kiss Szilvia - Koltányiné Vadász Viktória - Ugrai Zsuzsanna - Kósik Ferenc 2019. Projektalapú nyelvoktatás egyetemi hallgatók körében. Educatio 28/2: 392-402. https://doi.org/10.1556/2063.28.2019.2.13

Török Judit - Ugrai Zsuzsa 2017. A BGE KKK Német Tanszéki Osztály mühelymunkája a projektalapú nyelvoktatásról. Előadás a Regionális párbeszéd az idegennyelv tanításról címá konferencián. 2017. május 19. BGE, Zalaegerszeg.

\section{Internetes hivatkozások}

W1 = Diplomás pályakezdők a versenyszektorban. Gazdasági- és Vállalkozáselemző Intézet kutatásának záró tanulmánya 2011. http:/gvi.hu/kutatasaink/diplomasok (2018. 03. 05.)

W2 = Magyarországi vezérigazgatói felmérés 2017. https://www.pwc.com/hu/hu/ ceo/2017.html (2018. 02. 22.)

W3 = World Economic Forum 2016. The 10 skills you need to thrive in the Fourth Industrial Revolution. https:/www.weforum.org/agenda/2016/01/the-10-skills-youneed-to-thrive-in-the-fourth-industrial-revolution (2018. 04. 29.) 